\title{
Evaluation of source of corn silage and trace minerals on rumen characteristics and passage rate of Holstein cows
}

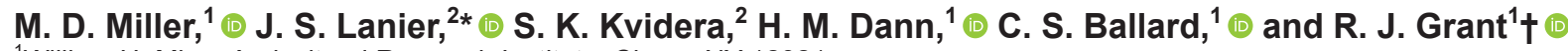 \\ ${ }^{1}$ William H. Miner Agricultural Research Institute, Chazy, NY 12921 \\ ${ }^{2}$ Micronutrients USA LLC, Indianapolis, IN 46241
}

\begin{abstract}
The effects of source of corn silage and trace mineral on rumen fermentation, turnover, and particle passage rates were evaluated with 8 ruminally cannulated Holstein cows averaging 83 (standard error $=5$ ) days in milk in a replicated $4 \times 4$ Latin square design with a $2 \times 2$ factorial arrangement of treatments and $28-\mathrm{d}$ periods. The diets consisted (dry basis) of $55 \%$ conventional (CON) or brown midrib-3 (BM3) corn silage, $2 \%$ chopped wheat straw, and $43 \%$ grain mix with either sulfate (STM) or hydroxy (HTM) source of $\mathrm{Cu}, \mathrm{Zn}$, and $\mathrm{Mn}$ trace minerals. The targeted supplemental amount of $\mathrm{Cu}, \mathrm{Zn}$, and $\mathrm{Mn}$ was 194, 1,657, and 687 $\mathrm{mg} / \mathrm{d}$, respectively. The dietary treatments were (1) CON-STM, (2) CON-HTM, (3) BM3-STM, and (4) BM3-HTM. Dietary nutrient composition of BM3 diets averaged $32.1 \%$ amylase neutral detergent fiber on an organic matter basis (aNDFom) and 6.9\% undigested neutral detergent fiber at $240 \mathrm{~h}$ of in vitro fermentation (uNDF240om; \% of dry matter), and CON diets averaged $36.2 \%$ aNDFom and $8.6 \%$ uNDF240om (\% of dry matter). Data were summarized by period and analyzed as a replicated Latin square design with fixed model effects for corn silage, trace mineral, corn silage and trace mineral interaction, period within replicated square, and replicated square using the MIXED procedure of SAS (version 9.4, SAS Institute Inc., Cary, NC). Cow within replicate was a random effect. Daily mean, standard deviation, minimum, and maximum for rumen $\mathrm{pH}$ were unaffected by corn silage or trace mineral source. Cows fed the CON diets had greater rumen acetate percentage than cows fed the BM3 diets (65.7 vs. 64.7 molar \%). In contrast, cows fed the BM3 diets had greater rumen propionate percentage than cows fed the CON diets (21.4 vs. 20.4 molar \%). Total volatile fatty acid concentration was lower for cows fed STM versus
\end{abstract}

Received March 9, 2020

Accepted May 19, 2020.

*Current address: Purina Animal Nutrition, Raleigh, NC 27615.

†Corresponding author: grant@whminer.com
HTM in BM3 diets, but not for the cows fed the CON diets. Cows fed the BM3 diets had faster turnover rate and shorter turnover time for uNDF240om than cows fed the CON diets (3.12 vs. $2.86 \% / \mathrm{h}$ and 33.3 vs. 36.5 $\mathrm{h}$, respectively). Cows fed the BM3 diets had a faster passage rate of small and medium corn silage neutral detergent fiber particles than cows fed the CON diets ( 5.73 vs. $5.37 \% / \mathrm{h}$ and 4.74 vs. $4.31 \% / \mathrm{h}$, respectively). We observed a corn silage by source of trace mineral interaction on organic matter and uNDF240om rumen pool size and organic matter turnover. Overall, source of corn silage had a pronounced influence on rumen dynamics presumably related to greater in vitro neutral detergent fiber digestibility and lower uNDF240om content of BM3 corn silage that allowed for faster turnover of indigestible neutral detergent fiber and greater passage rate of corn silage particles. In contrast, the source of trace mineral had much less significant effects on rumen fermentation, turnover, and particle passage rates. Corn silage-based diets intended to enhance rumen fiber fermentation, turnover, and passage are more affected by source and digestibility of neutral detergent fiber than source of dietary trace minerals.

Key words: trace mineral, corn silage, passage rate, rumen $\mathrm{pH}$

\section{INTRODUCTION}

Forages are the major feedstuff that provides fiber for dairy cows, and both physical and chemical characteristics will affect rumen fermentation, digestibility, and energy value (Allen and Mertens, 1988). Corn silage provides digestible and physically effective fiber, as well as starch, which has led to increased inclusion of this forage in dairy cow diets (Hassanat et al., 2017). In fact, corn silage is the most commonly fed forage in the United States and its production has increased more than 30\% since the 1980s (Grant and Adesogan, 2018).

Brown midrib corn silage has a gene mutation, either brown midrib-1 or brown midrib-3, that reduces the lignin content and enhances NDF digestibility compared with non-brown midrib hybrids (Oba and Allen, 1999; 
Hassanat et al., 2017). In a corn silage hybrid study replicated over $3 \mathrm{yr}$, brown midrib-3 hybrids had greater NDF digestibility, lower indigestible NDF (iNDF), and higher potentially digestible NDF (NDF - iNDF) than either brown midrib-1 or non-brown midrib hybrids (Miller et al., 2018). In previous studies, lactating cows fed brown midrib-3 corn silage had lower rumen fill and greater DMI than cows fed diets with conventional corn silage due to a lower iNDF fraction and greater fiber passage rates from the rumen for brown midrib-3 corn silage (Oba and Allen, 1999, 2000a,b; Hassanat et al., 2017). Undigested NDF residue on an OM basis (uNDF240om) is a laboratory measure of iNDF and has been related to NDF digestion and passage kinetics, gut fill and intake, and physical effectiveness of fiber (Nousiainen et al., 2003; Cotanch et al., 2014; Raffrenato et al., 2018).

In contrast to corn silage, relatively little research has focused on the role of trace mineral source on rumen fiber fermentability, turnover, and DMI. Rumen microorganisms require some trace minerals for proper function, although the release of free metal from the mineral in the rumen could reduce its bioavailability to the cow. Different sources of trace minerals have varying stabilities in the rumen and may affect rumen fermentation. Importantly, hydroxy trace minerals (HTM) are less soluble in the rumen compared with sulfate sources (Torre et al., 1991; Cao et al., 2000; Spears et al., 2004; Genther and Hansen, 2015; Caldera et al., 2019). Faulkner and Weiss (2017) reported that feeding sulfate sources of $\mathrm{Cu}, \mathrm{Mn}$, and $\mathrm{Zn}$ minerals decreased total-tract NDF digestibility compared with hydroxy $\mathrm{Cu}, \mathrm{Mn}$, and $\mathrm{Zn}$ minerals in forage- and byproductbased dairy cattle diets. Feeding dairy heifers organic trace minerals of $\mathrm{Cu}, \mathrm{Zn}, \mathrm{Mn}$, Se, and Co resulted in lower rumen $\mathrm{pH}$ and greater total VFA concentrations compared with dairy heifers fed sulfate trace minerals (STM; Pino and Heinrichs, 2016). Taken together, these results suggest that source of trace mineral affects rumen fermentation.

However, to date no study has assessed the interaction between source of forage fiber and the source of trace minerals on rumen fermentation, turnover, and particle passage rates in diets fed to lactating dairy cows. Therefore, the objective of this study was to evaluate the effect of source of corn silage (brown midrib-3 or conventional) and source of trace minerals (hydroxy or sulfate) on rumen characteristics and particle passage rate in lactating Holstein cows. Our hypothesis was that brown midrib-3 corn silage would positively affect rumen fermentation and fiber turnover characteristics, and STM would negatively affect rumen fermentation and fiber turnover characteristics with this negative ef- fect being greater in diets containing conventional corn silage.

\section{MATERIALS AND METHODS}

\section{Experimental Design, Diets, and Management of Cows}

This paper is a companion study to Miller et al. (2020), and focuses on rumen characteristics and particle passage rate using a subset of 8 ruminally cannulated, multiparous cows.

All experimental procedures involving animals were approved by the William H. Miner Agricultural Research Institute Animal Care and Use Committee. The study was conducted at the William H. Miner Agricultural Research Institute (Chazy, NY) in the Charles J. Sniffen Dairy Research and Education Complex. Eight ruminally cannulated, multiparous lactating Holstein cows averaging $83 \pm 5$ (SE) DIM at the beginning of the experiment were blocked by cannulation status, DIM, and milk production and were used in a replicated 4 $\times 4$ Latin square design with a $2 \times 2$ factorial arrangement of treatments. The study had 28 -d periods. Each square was conducted concurrently, with the first $17 \mathrm{~d}$ serving as an adaption period, and the last $11 \mathrm{~d}$ serving as the collection period. Cows were enrolled on the study $14 \mathrm{~d}$ before period 1 began and were fed a TMR with no supplemental trace minerals or monensin (Elanco Animal Health, Greenfield, IN).

Dietary treatments (Table 1) were formulated to contain either conventional (CON; Doebler 554GRQ, Doebler's PA Hybrids, Williamsport, PA) or brown midrib-3 corn silage (BM3; Mycogen F2F499, Dow AgroSciences LLC, Indianapolis, IN) and either a sulfate (STM) source of $\mathrm{Cu}, \mathrm{Zn}$, and $\mathrm{Mn}$ or a hydroxy source of trace minerals (HTM; IntelliBond C, Z, and M, Micronutrients USA LLC, Indianapolis, IN). The diets were formulated to contain $54.5 \%$ (DM basis) of either BM3 or CON corn silage so that the differences in fiber fractions among the diets were determined primarily by the source of corn silage. The targeted supplemental amount of $\mathrm{Cu}, \mathrm{Zn}$, and $\mathrm{Mn}$ was 194 , 1,657 , and $687 \mathrm{mg} / \mathrm{d}$, respectively. The 4 dietary treatments were (1) CON silage and sulfate trace minerals (CON-STM), (2) CON silage and hydroxy trace minerals (CON-HTM), (3) BM3 silage and sulfate trace minerals (BM3-STM), and (4) BM3 silage and hydroxy trace minerals (BM3-HTM). Diets were formulated using Cornell Net Carbohydrate Protein System biology (AMTS.Cattle.Professional, version 4.8, Agricultural Modeling \& Training systems, LLC, Groton, NY). Inputs used for diet formulation included $29.9 \mathrm{~kg} / \mathrm{d}$ of 
DMI, $54 \mathrm{~kg} / \mathrm{d}$ of milk with $3.60 \%$ fat and $3.05 \%$ true protein, and $750 \mathrm{~kg}$ of BW. Cows were fed the diets as TMR for ad libitum intake (approximately $1.15 \times$ expected intake) once daily (fed at $1400 \mathrm{~h}$; Calan Data Ranger, American Calan Inc., Northwood, NH) in a tiestall barn equipped with individual feed boxes.

\section{Data Collection, Sample Procedures, and Analytical Methods}

Forages, diets, and orts were collected 3 times per week during d 1 to 17 and daily for d 18 to 28 . Grain mixes were collected once per week during d 1 to 17 and daily from d 18 to 28 . A portion of each sample was dried in a forced-air oven at $105^{\circ} \mathrm{C}$ for $24 \pm 6 \mathrm{~h}$ for $\mathrm{DM}$ determination. Diets were adjusted for changes in DM content of the feed ingredients when a feed ingredient $\mathrm{DM}$ value was outside the range of the $\mathrm{DM}$ mean \pm 1.2 standard deviations or a new feed ingredient source was used or delivered.

Starting on d 18 of each period, a portion of the feed ingredients, diets, and orts collected daily was stored frozen at $-20^{\circ} \mathrm{C}$, and then was composited by period by combining equal volumes of the daily as-fed samples. The composites of feed ingredients were analyzed for chemical composition (CPM Plus, Cumberland Valley Analytical Services Inc., Waynesboro, PA). Analyses included DM, ash (method 942.05; AOAC International, 2012), OM (method 942.05; AOAC International, 2012), CP (method 990.03; AOAC International, 2012), soluble protein according to Krishnamoorthy et al. (1982), fat (method 2003.05; AOAC International, 2012), ADF (method 973.18; AOAC International, 2012), NDF using $\alpha$-amylase, sodium sulfite, and ashcorrected (Van Soest et al., 1991), ADL (Goering and Van Soest, 1970), starch according to Hall (2009), sugar as ethanol-soluble carbohydrates according to DuBois et al. (1956), and minerals (method 985.01; AOAC International, 2012).

Fiber characteristics and NDF digestibility at 30 $\mathrm{h}$ were determined on the forage and grain composite samples (Cumberland Valley Analytical Services Inc.). Undigested NDF at 30-, 120-, and 240-h time points (uNDF30om, uNDF120om, uNDF240om, respectively) for forages and undigested NDF at 12-, 72-, and 120-h time points (uNDF12om, uNDF72om, and uNDF120om) for grains were assessed using an in vitro rumen fermentation system (Raffrenato et al., 2018; Cumberland Valley Analytical Services Inc.). Starch digestibility at $7 \mathrm{~h}$ (Hall, 2009; Cumberland Valley Analytical Services Inc.) was determined on the period composite samples of corn silage and grain mixes. A portion of the forage and diet composite samples was used to determine particle size distribution on an as-fed basis using a Penn State Particle Separator (Lammers et al., 1996) modified to include a 4 -mm screen. A portion of the period composite for forage and grain mixes was also used to determine particle size distribution on a $\mathrm{DM}$ basis $\left(55^{\circ} \mathrm{C}\right)$ by dry vertical sieving (Ro-Tap testing sieve shaker model B; W. S. Tyler Combustion Engineering Inc., Mentor, OH). The physical effectiveness factor (pef) was defined as the fraction of particles retained on the 1.18-mm screen or greater (for dry sieving) or the 4.0-mm screen and greater (for as-fed sieving). Physically effective NDF (peNDF) of a forage or diet was calculated as the product of its NDF content and its pef (Mertens, 1997).

Rumen $\mathrm{pH}$ was measured in ruminally cannulated cows $(\mathrm{n}=8)$ with an indwelling rumen $\mathrm{pH} / \mathrm{ORP} /$ REDOX measurement system (Penner et al., 2006; LRCpH, Dascor, Escondido, CA) at 1-min intervals for a $96-\mathrm{h}$ period starting on d 23 of each period. Rumen $\mathrm{pH}$ measurements were averaged over a 10-min period within day and summarized as mean $\mathrm{pH}$, minimum $\mathrm{pH}$, maximum $\mathrm{pH}, \mathrm{pH}$ range, the area that the $\mathrm{pH}$ curve was below a $\mathrm{pH}$ of 5.8 (AUC), and minutes per day that $\mathrm{pH}$ was below 5.5 or 5.8 (Beauchemin and Yang, 2005).

Samples of rumen fluid (approximately $500 \mathrm{~mL}$ ) were collected from beneath the rumen digesta mat at 4-h intervals for $24 \mathrm{~h}$ starting at the beginning of d 26 of each period. Cows were sampled based on their square assignment. Feeding and the associated sampling times were staggered by $10 \mathrm{~min}$ between squares of cows to allow for collection of samples at desired times. Samples were strained through 4 layers of cheesecloth. A portion of each sample of rumen fluid (approximately $40 \mathrm{~mL}$ ) was frozen and stored at $-20^{\circ} \mathrm{C}$ until analysis for VFA concentration (Bulletin 856B, Supelco Inc., Bellefonte, PA). Volatile fatty acid concentration was determined by GC with use of a Varian CP-3800 gas chromatograph (Varian Inc., Palo Alto, CA) equipped with a flame-ionization detector and an 80/120 Carbopack B-DA/4\% Carbowax 20M column (Supelco Inc.). Ten $\mathrm{mL}$ of rumen fluid was added to $100 \mu \mathrm{L}$ of concentrated $\mathrm{HCl}$ and frozen at $-20^{\circ} \mathrm{C}$ until analysis of rumen $\mathrm{NH}_{3}-$ $\mathrm{N}$ concentration (Chaney and Marbach, 1962).

Rumen contents of cows $(n=8)$ were evacuated manually through the rumen cannula after daily feeding on $d 27$ and at the end of d 28. To ensure that cows experienced the same interval of time between rumen evacuations, cows were divided into 2 groups of 4 cows each based on square. The first group was evacuated $3.5 \mathrm{~h}$ after feeding on $\mathrm{d} 27(1730 \mathrm{~h})$ and $20.5 \mathrm{~h}$ after feeding on d $28(1030 \mathrm{~h})$. The second group of cows was evacuated $4.5 \mathrm{~h}$ after feeding on $\mathrm{d} 27(1830 \mathrm{~h})$ and $19.5 \mathrm{~h}$ after feeding on $\mathrm{d} 28(0930 \mathrm{~h})$. The mass and volume of rumen contents were determined. Dur- 
Table 1. Ingredient composition (expressed as a percentage of DM) of diets containing either conventional corn silage $(\mathrm{CON})$ or brown midrib corn silage (BM3) with either sulfate trace minerals (STM) or hydroxy trace minerals (HTM) fed to lactating Holstein cows

\begin{tabular}{|c|c|c|c|c|}
\hline \multirow[b]{3}{*}{ Item } & \multicolumn{4}{|c|}{ Diet } \\
\hline & \multicolumn{2}{|c|}{$\mathrm{CON}$} & \multicolumn{2}{|c|}{ BM3 } \\
\hline & STM & HTM & STM & HTM \\
\hline Conventional corn silage $(\mathrm{CON})$ & 54.56 & 54.56 & - & - \\
\hline Brown midrib corn silage (BM3) & - & - & 54.55 & 54.55 \\
\hline Straw & 2.27 & 2.27 & 2.27 & 2.27 \\
\hline Beet pulp (pellets) & 6.82 & 6.82 & 6.82 & 6.82 \\
\hline Corn meal & 2.67 & 2.67 & 2.67 & 2.67 \\
\hline \multicolumn{5}{|l|}{ Concentrate mix } \\
\hline Soy hull & 7.31 & 7.31 & 3.07 & 3.07 \\
\hline Protein supplement $^{1}$ & 6.59 & 6.59 & 5.27 & 5.27 \\
\hline Soybean meal & 5.30 & 5.30 & 6.67 & 6.67 \\
\hline Corn meal & 1.71 & 1.71 & 5.60 & 5.60 \\
\hline Canola meal & 2.69 & 2.69 & 4.02 & 4.02 \\
\hline $99 \%$ Sugar & 1.41 & 1.41 & 1.41 & 1.41 \\
\hline Dried distillers grains & 1.34 & 1.34 & - & - \\
\hline Fat supplement $1^{2}$ & 1.21 & 1.21 & 1.21 & 1.21 \\
\hline Calcium carbonate & 1.10 & 1.11 & 1.10 & 1.11 \\
\hline Protein supplement $^{3}$ & 0.86 & 0.86 & 1.17 & 1.17 \\
\hline Molasses & 0.82 & 0.82 & 0.82 & 0.82 \\
\hline Sodium sesquicarbonate & 0.73 & 0.73 & 0.73 & 0.73 \\
\hline Potassium carbonate $^{4}$ & 0.59 & 0.59 & 0.59 & 0.59 \\
\hline Fat supplement $2^{5}$ & 0.59 & 0.59 & 0.59 & 0.59 \\
\hline Salt & 0.38 & 0.38 & 0.38 & 0.38 \\
\hline Urea & 0.37 & 0.37 & 0.37 & 0.37 \\
\hline Magnesium oxide & 0.31 & 0.31 & 0.31 & 0.31 \\
\hline Monodicalcium phosphate & 0.12 & 0.12 & 0.12 & 0.12 \\
\hline Selenium yeast $0.06 \%{ }^{6}$ & 0.05 & 0.05 & 0.05 & 0.05 \\
\hline Calcium chloride & 0.04 & 0.04 & 0.04 & 0.04 \\
\hline Vitamin $\mathrm{E}^{7}$ & 0.03 & 0.03 & 0.03 & 0.03 \\
\hline Fly larvicide $^{8}$ & 0.03 & 0.03 & 0.03 & 0.03 \\
\hline Methionine analog 9 & 0.02 & 0.02 & 0.04 & 0.04 \\
\hline Vitamin $\mathrm{E}^{10}$ & 0.02 & 0.02 & 0.02 & 0.02 \\
\hline Rumen-protected methionine ${ }^{11}$ & 0.01 & 0.01 & 0.01 & 0.01 \\
\hline Copper sulfate & 0.004 & - & 0.004 & - \\
\hline Manganese sulfate & 0.012 & - & 0.012 & - \\
\hline Zinc sulfate & 0.017 & - & 0.017 & - \\
\hline Hydroxy $\mathrm{Cu}^{12}$ & - & 0.002 & - & 0.002 \\
\hline Hydroxy $\mathrm{Zn}^{12}$ & - & 0.009 & - & 0.009 \\
\hline Hydroxy $\mathrm{Mn}^{12}$ & - & 0.011 & - & 0.011 \\
\hline Vitamin $A^{13}$ & 0.0003 & 0.0003 & 0.0003 & 0.0003 \\
\hline Vitamin $\mathrm{D}^{14}$ & 0.0002 & 0.0002 & 0.0002 & 0.0002 \\
\hline Cobalt carbonate & 0.0002 & 0.0002 & 0.0002 & 0.0002 \\
\hline Potassium iodide & 0.0001 & 0.0001 & 0.0001 & 0.0001 \\
\hline Total & 100 & 100 & 100 & 100 \\
\hline
\end{tabular}

${ }^{1}$ Aminomax Pro, Afgritech, LLC, Watertown, NY

${ }^{2}$ BergaFat, Berg + Schmidt America, LLC, Libertyville, IL.

${ }^{3}$ PGI Amino Enhancer, Poulin Grain, Newport, VT.

${ }^{4}$ DCAD Plus, Arm \& Hammer Animal Nutrition, Ewing, NJ.

${ }^{5}$ Energizer Gold, IFFCO (Malaysia) SDN.BHD, Sharjah, United Arab Emirates.

${ }^{6}$ Co-operative Feed Dealers Inc., Conklin, NY.

${ }^{7}$ Contained 500,000 IU of vitamin E/kg \% of DM.

${ }^{8}$ Clarifly, 0.67\%, Central Garden and Pet Company, Schaumburg, IL

${ }^{9}$ MetaSmart, Adisseo USA Inc., Alpharetta, GA.

${ }^{10}$ Contained 8,816 IU of vitamin $\mathrm{E} / \mathrm{kg} \%$ of DM.

${ }^{11}$ Smartamine, Adisseo USA Inc.

${ }^{12}$ Intellibond C, Z, M, Intellibond, Micronutrients USA LLC, Indianapolis, IN.

${ }^{13}$ Contained 1,000,000 IU of vitamin A/g \% of DM.

${ }^{14}$ Contained 500,000 IU of vitamin D/g \% of DM. 
ing the evacuation, approximately $10 \%$ of the rumen contents were subsampled and squeezed through a nylon screen (1-mm pore size) to separate solid and liquid phases, and each phase was weighed. Aliquots (approximately $300 \mathrm{~g}$ ) from both the solid and liquid phases were collected, frozen at $-20^{\circ} \mathrm{C}$, dried at $55^{\circ} \mathrm{C}$, ground (solids: 1-mm screen, Wiley mill; Arthur H. Thomas, Philadelphia, PA; liquid: 2-mm screen, UDY Cyclone Sample Mill; UDY Corp., Fort Collins, CO), and recombined based on the proportion of DM of each phase. The recombined rumen contents were analyzed for ash (modified method 942.05; AOAC International, $2012 ; 4 \mathrm{~h}$ at $600^{\circ} \mathrm{C}$ ), aNDFom (as described previously), uNDF240om, and starch (Hall, 2009; Raffrenato et al., 2018; Cumberland Valley Analytical Services Inc.). The remaining rumen contents were returned to the cow within 60 min of initiating the evacuation.

Rumen pool size of OM, NDF, uNDF240om, and starch was calculated as the product of the DM mass of the rumen contents and the nutrient content of the rumen contents. Rumen turnover rate $(\% / \mathrm{h})$ of $\mathrm{OM}$, NDF, uNDF240om, and starch was calculated as $[100 \times$ (intake of nutrient/rumen pool of nutrient)/24] (Voelker Linton and Allen, 2008). Nutrient intake was calculated using DMI from d 27 and 28 and the nutrient content of the diets from d 18 to 28 . Rumen turnover time (h) was calculated as $1 /[$ rumen turnover rate $(\% / \mathrm{h}) / 100]$.

Rates of passage of liquid, small, medium, and large particles were determined by chemical marker. Before start of the study, approximately $150 \mathrm{~kg}$ of conventional and brown midrib-3 corn silages were collected and dried in a forced-air oven at $55^{\circ} \mathrm{C}$ for $24 \mathrm{~h}$. Dry silages were hand shaken through a $3.2-\mathrm{mm}$ screen to separate the large and small particles. The dry silages that did not pass the $3.2-\mathrm{mm}$ screen were soaked in a barrel of tap water, approximately $2 \mathrm{~kg}$ at a time, and all floating particles were skimmed off the top and retained, with the heavier kernels of starch sinking to the bottom and not being retained. The fibrous fraction was skimmed from the barrel and the silage particles that passed a $3.2-\mathrm{mm}$ screen were boiled in a solution of $3 \%$ sodium lauryl sulfate for $1 \mathrm{~h}$, and were agitated at intervals of approximately $10 \mathrm{~min}$. After boiling, the fibrous silage particles were placed in fine mesh bags and rinsed with warm tap water in a washing machine on rinse and spin cycles 6 to 8 times. This material was dried in a forced-air oven for $24 \mathrm{~h}$ at $55^{\circ} \mathrm{C}$ and separated by dry vertical sieving (Ro-Tap testing sieve shaker model B; W. S. Tyler Combustion Engineering Inc.) with 19.00-, 13.20-, 9.50-, 6.70-, 4.75-, 3.35-, 2.36-, 1.18-, 0.60-, and 0.30-mm sieves for $5 \mathrm{~min}$. Particle sizes were classified according to Mertens (2005), whereby particles passing through the $1.18-\mathrm{mm}$ screen but retained on the $0.30-\mathrm{mm}$ screen were labeled small particles, particles retained on the $1.18-\mathrm{mm}$ screen but passing through the $4.75-\mathrm{mm}$ screen were combined and labeled medium particles, and all particles retained on the 4.75 - to $19.00-\mathrm{mm}$ screens were combined and labeled as large particles. Particles passing through the $0.30-\mathrm{mm}$ screen were discarded. Small, medium, and large particles of conventional and brown midrib-3 corn silage NDF were soaked in rare earth acetates of Sm, $\mathrm{Yb}$, and $\mathrm{Pr}$, respectively, at a concentration of $50 \mathrm{mg}$ of rare earth to $1,000 \mathrm{mg}$ of corn silage NDF particles for $48 \mathrm{~h}$ according to the methods of Ellis and Beever (1984), with the exception that a solution of $0.1 \mathrm{M}$ acetic acid was used to rinse particles for $3 \mathrm{~h}$ after marking with the rare earth acetate.

Cows were dosed with $310 \mathrm{~g}$ of the appropriate large and medium silage NDF particles, and $100 \mathrm{~g}$ of small conventional or brown midrib-3 corn silage NDF, depending on the source of corn silage in the treatment diet, at time of fresh feed delivery on d 18. All particles were combined, hydrated with tap water to achieve approximately $50 \%$ DM, mixed with $3 \mathrm{~L}$ of as-fed TMR, and offered to the cows before feeding. Any portion of the dose not consumed within 20 min was manually administered through the rumen cannula and mixed with the top mat of rumen contents. Additionally, a Na Co-EDTA solution was prepared according to Udén et al. (1980) for determination of liquid passage rate. Twenty grams of Na Co-EDTA was dissolved in $500 \mathrm{~mL}$ of reverse osmosis-treated $\mathrm{H}_{2} \mathrm{O}$ and pulse dosed into the rumen before feeding on d 18 .

Fecal samples were collected from the rectum at 0,3 , $6,9,12,18,24,30,36,42,48,60,72,84,96,120,144$, and $168 \mathrm{~h}$ after dosing. Fecal samples were dried at $55^{\circ} \mathrm{C}$ for $48 \mathrm{~h}$, ground (1-mm screen, Wiley Mill, Arthur H. Thomas), and analyzed using inductively-coupled plasma atomic emission spectroscopy (Cornell College of Agriculture and Life Sciences Nutrient Analysis Laboratory, Ithaca, NY). Solid and liquid passage rates were calculated according to Grovum and Williams (1973) using the $\mathrm{lm}$ function of $\mathrm{R}$ version 3.5.2 ( $\mathrm{R}$ Core Team, 2014).

\section{Statistical Analysis}

Repeated measurements of performance data from the collection period (i.e., rumen $\mathrm{pH}$, rumen VFA, rumen digestion kinetics, and passage rate) were reduced to period means for each cow before statistical analysis. Data with a normal distribution (rumen $\mathrm{pH}$, rumen VFA, rumen digestion kinetics, and passage rate) were analyzed as a replicated Latin square design (Latin rectangle) with fixed effects of corn silage, trace mineral, corn silage and trace mineral interaction, period within replicated square, and replicated square 
using the MIXED procedure of SAS (version 9.4, SAS Institute Inc., Cary, NC). Cow within replicate was a random effect.

Data that followed a nonnormal distribution (i.e., $\mathrm{pH}$ range, AUC $<5.8, \mathrm{pH}<5.8, \mathrm{pH}<5.5$, propionate concentration, starch turnover rate, particle passage rate, and mean retention time of large particles) were analyzed using an alternative distribution (negative binomial with log link function) that optimized the chi-squared statistic using the GLIMMIX procedure of SAS. Data were analyzed as a replicated Latin square design (Latin rectangle) with fixed effects of corn silage, trace mineral, corn silage and trace mineral interaction, period within replicated square, and replicated square. Cow within replicate was a random effect. Data from this analysis are reported based on the mean using the ilink function.

Least squares means were separated using the Tukey's procedure for MIXED and GLIMMIX procedure when a significant $F$-test $(P \leq 0.05)$ was detected. Significance was declared at $P \leq 0.05$ and trends at $0.05<$ $P \leq 0.10$.

\section{RESULTS AND DISCUSSION}

\section{Dietary Ingredient and Nutrient Composition}

The dietary ingredient and nutrient composition are discussed thoroughly in Miller et al. (2020) and will be briefly described here. The NDF content averaged 41.9 and $39.1 \%$ for CON and BM3 corn silage, respectively (Tables 2 and 3). The CON corn silage had an unexpected change in starch content during periods 3 and 4 compared with periods 1 and 2 of the study (29.6 vs. $35.6 \%$ of DM), and consequently starch content was lower for CON than the BM3 corn silage (32.8 vs. $36.0 \%$ of DM). The BM3 corn silage had a 9.7 percentage-unit greater NDF digestibility at $30 \mathrm{~h}$ and a 2.8 percentage-unit lower uNDF240om content compared with the CON corn silage (68.4 vs. $58.7 \%$ of aNDFom; 7.8 vs. $10.6 \%$ of DM, respectively). These relative differences in NDF content and digestibility were expected based on previous literature comparing brown midrib-3 and conventional corn silage hybrids (Oba and Allen, 2000b; Hassanat et al., 2017; Miller et al., 2018).

The calculated chemical composition and fiber fractions of the treatment diets (based on analysis of individual ingredients) are shown in Tables 4 and 5. More detailed information for individual feed ingredients may be found in Miller et al. (2020). The CON diets had numerically greater aNDFom and lower starch content than the brown midrib diets due to the greater aNDFom and lower starch content of the CON corn silage (36.2 vs. $32.1 \%$ of DM; 21.9 vs. $26.2 \%$ of DM, respectively). The NDF digestibility at $30 \mathrm{~h}$ was numerically greater for the BM3 diets compared with the $\mathrm{CON}$ diets and the uNDF240om was numerically lower for the BM3 diets compared with the CON diets $(62.0$ vs. $55.7 \%$ of aNDFom; 6.9 vs. $8.6 \%$ of DM, respectively). As expected, the pef among the diets was similar and the peNDF content of the CON diets was greater than BM3 diets (24.1\% vs. $21.9 \%$, respectively), which can be attributed to differences in aNDFom content in each diet and not particle size distribution. The overall TMR composition primarily reflected compositional differences between the 2 sources of corn silage.

The supplemental and total dietary trace mineral concentrations were numerically similar among diets as concentrations of trace minerals were kept constant across diets, but the source was either STM or HTM and differed among diets, as shown in Table 6. The concentrations of trace minerals were chosen to be similar to on-farm diets for high-producing dairy cows and purposely exceeded NRC (2001) guidelines.

In summary, we anticipated that the response to diet would be a function of source of corn silage and trace minerals. Although we had intended for the silage to differ mainly in NDF digestibility, the unexpected variation in starch content during the course of the study means that any measured effect of corn silage will be a combination of NDF and starch effects.

\section{Intake, Milk, and BW Responses}

The subset of 8 cannulated, multiparous cows used for the rumen measures had DMI, milk, and BW responses to diet that were similar to the entire group of 14 cows reported in Miller et al. (2020). Specifically, the same 1-kg increase in DMI occurred for cows fed the BM3-HTM diet versus the other 3 diets (29.2 versus $28.2 \mathrm{~kg} / \mathrm{d} ; P<0.16)$ just as in Miller et al. (2020), but with the smaller number of cows the effect was not significant. Milk yield was greater for cows fed the BM3-HTM diet relative to the other diets (49.5 versus $47.2 \mathrm{~kg} / \mathrm{d} ; P<0.02)$, which agrees with the responses observed by Miller et al. (2020) for the larger group of 14 cows.

Overall, the cannulated cows fed the CON and BM3STM diets had $0.7 \mathrm{~kg}$ greater DMI compared with the entire group of 14 cows fed the CON and BM3-STM diets (28.2 vs. $27.5 \mathrm{~kg} / \mathrm{d}$, respectively). The cannulated cows fed the BM3-HTM diet had $0.6 \mathrm{~kg}$ greater DMI compared with the entire group of 14 cows fed the BM3-HTM (29.2 vs. $28.6 \mathrm{~kg} / \mathrm{d}$ ). The cannulated cows had a greater average BW of $688 \mathrm{~kg}$ compared with the entire group BW of $665 \mathrm{~kg}$. The cannulated cows fed the BM3 diets had $0.6 \mathrm{~kg}$ greater ECM yield compared 
Table 2. Data (mean $\pm \mathrm{SD}$ ) characterizing the analyzed chemical composition of feed ingredients fed to lactating Holstein cows

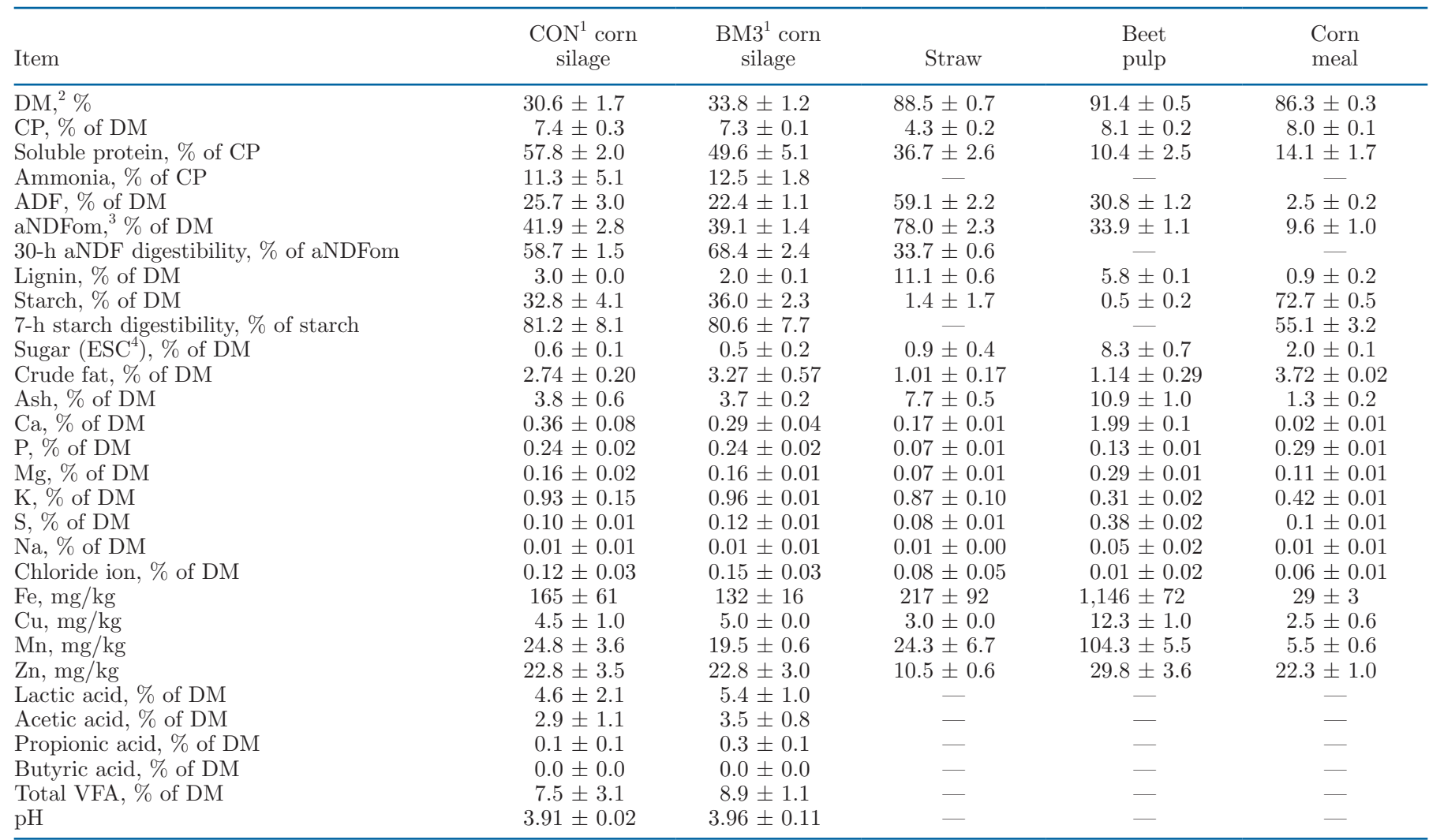

${ }^{1}$ Conventional corn silage (CON) or brown midrib corn silage (BM3).

${ }^{2}$ For DM analysis, $\mathrm{n}=44$ for CON and BM3 corn silage and straw; $\mathrm{n}=8$ for beet pulp and corn meal.

${ }^{3}$ aNDFom $=$ amylase neutral detergent fiber on an organic matter basis.

${ }^{4}$ Ethanol-soluble carbohydrates.

with the entire group fed the BM3 diets (48.1 vs. 47.6 $\mathrm{kg} / \mathrm{d})$, whereas the cannulated cows fed the CON diets had $0.9 \mathrm{~kg}$ greater ECM yield compared with the entire group fed the CON diets (47.1 vs. $46.2 \mathrm{~kg} / \mathrm{d}$ ).

In summary, the cannulated cows used in this study had slightly greater DMI, BW, and milk yield than the entire group of 14 cows reported in Miller et al. (2020), but the pattern of response to diet was similar between the studies.

\section{Rumen pH and VFA}

Rumen $\mathrm{pH}$ data are presented in Table 7. Minutes below rumen $\mathrm{pH}$ of 5.8 showed a tendency for a corn

Table 3. Data (mean $\pm \mathrm{SD}$ ) characterizing the fiber fractions of feed ingredients fed to lactating Holstein cows

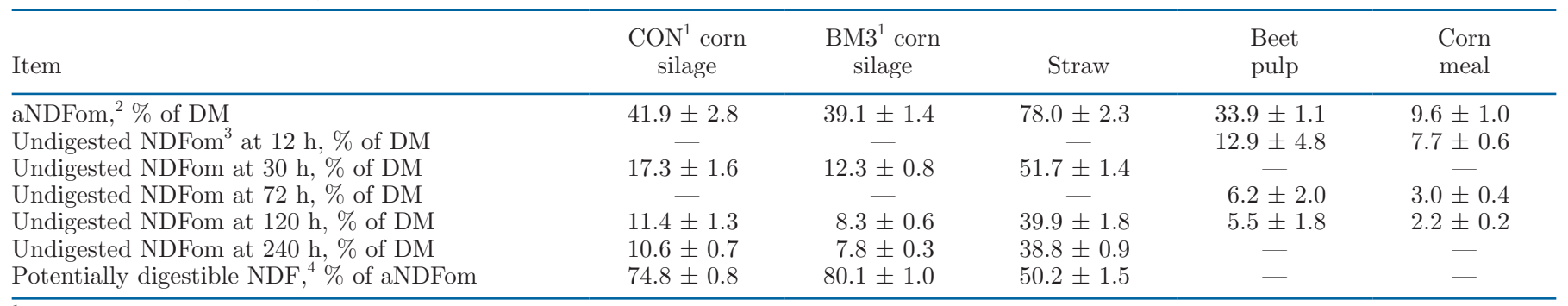

${ }^{1}$ Conventional corn silage (CON) or brown midrib corn silage (BM3).

${ }^{2}$ Amylase neutral detergent fiber on an organic matter basis.

${ }^{3} \mathrm{NDFom}=$ neutral detergent fiber on an organic matter basis.

${ }^{4}$ Potentially digestible NDF $=($ aNDFom - undigested NDFom at $240 \mathrm{~h}) /$ aNDFom. 
Table 4. Calculated diet composition based on chemical analysis of ingredients in diets containing either conventional corn silage (CON) or brown midrib corn silage (BM3) with either sulfate trace minerals (STM) or hydroxy trace minerals (HTM) fed to lactating Holstein cows

\begin{tabular}{|c|c|c|c|c|}
\hline Item & \multicolumn{4}{|c|}{ Diet } \\
\hline $\mathrm{DM},{ }^{1} \%$ & $43.5 \pm 2.0^{2}$ & $43.7 \pm 1.6$ & $45.9 \pm 1.2$ & $46.4 \pm 1.3$ \\
\hline $\mathrm{CP}, \%$ of $\mathrm{DM}$ & $15.0 \pm 0.4$ & $15.3 \pm 0.3$ & $15.6 \pm 0.5$ & $15.4 \pm 0.2$ \\
\hline Soluble protein, $\%$ of $\mathrm{CP}$ & $40.3 \pm 1.9$ & $41.0 \pm 2.0$ & $36.3 \pm 4.0$ & $35.6 \pm 3.4$ \\
\hline Lignin, \% of DM & $3.4 \pm 0.1$ & $3.4 \pm 0.1$ & $2.7 \pm 0.1$ & $2.8 \pm 0.1$ \\
\hline Starch, \% of DM & $21.8 \pm 2.4$ & $21.9 \pm 2.4$ & $26.2 \pm 1.3$ & $26.1 \pm 1.2$ \\
\hline Sugar $\left(\mathrm{ESC}^{4}\right), \%$ of DM & $4.1 \pm 0.3$ & $4.1 \pm 0.1$ & $4.0 \pm 0.3$ & $3.9 \pm 0.2$ \\
\hline Crude fat, $\%$ of DM & $3.0 \pm 0.4$ & $3.0 \pm 0.4$ & $3.2 \pm 0.6$ & $3.3 \pm 0.5$ \\
\hline Ash, \% of DM & $8.12 \pm 0.33$ & $8.06 \pm 0.43$ & $7.91 \pm 0.28$ & $7.74 \pm 0.62$ \\
\hline $\mathrm{Ca}, \%$ of $\mathrm{DM}$ & $1.14 \pm 0.07$ & $1.17 \pm 0.02$ & $1.07 \pm 0.05$ & $1.05 \pm 0.10$ \\
\hline $\mathrm{P}, \%$ of $\mathrm{DM}$ & $0.35 \pm 0.01$ & $0.36 \pm 0.0$ & $0.36 \pm 0.01$ & $0.35 \pm 0.01$ \\
\hline $\mathrm{Fe}, \mathrm{mg} / \mathrm{kg}$ of $\mathrm{DM}$ & $306 \pm 33$ & $310 \pm 36$ & $275 \pm 14$ & $274 \pm 14$ \\
\hline $\mathrm{Cu}, \mathrm{mg} / \mathrm{kg}$ of $\mathrm{DM}$ & $18 \pm 0.7$ & $17 \pm 1.1$ & $17 \pm 1.2$ & $16 \pm 0.8$ \\
\hline $\mathrm{Mn}, \mathrm{mg} / \mathrm{kg}$ of $\mathrm{DM}$ & $61 \pm 4$ & $68 \pm 2$ & $60 \pm 8$ & $64 \pm 5$ \\
\hline $\mathrm{Zn}, \mathrm{mg} / \mathrm{kg}$ of $\mathrm{DM}$ & $101 \pm 20$ & $93 \pm 3$ & $107 \pm 30$ & $88 \pm 6$ \\
\hline
\end{tabular}

${ }^{1}$ Diets were analyzed for $\mathrm{DM}$ at $105^{\circ} \mathrm{C} ; \mathrm{n}=44$ for each diet. For all other analyses, $\mathrm{n}=4$.

${ }^{2}$ Mean \pm SD.

${ }^{3}$ aNDFom $=$ amylase neutral detergent fiber on an organic matter basis.

${ }^{4}$ Ethanol-soluble carbohydrates.

Table 5. Data (mean $\pm \mathrm{SD}$ ) characterizing the fiber fractions and particle size of diets containing either conventional corn silage (CON) or brown midrib corn silage (BM3) with either sulfate trace minerals (STM) or hydroxy trace minerals (HTM) fed to lactating Holstein cows

\begin{tabular}{|c|c|c|c|c|}
\hline Item & \multicolumn{4}{|c|}{ Diet } \\
\hline aNDFom, ${ }^{1} \%$ of DM & $36.3 \pm 2.1$ & $36.0 \pm 2.1$ & $32.1 \pm 0.9$ & $32.0 \pm 0.9$ \\
\hline 30-h aNDF digestibility, $\%$ of aNDFom & $56.0 \pm 2.4$ & $55.3 \pm 4.4$ & $61.9 \pm 2.1$ & $62.0 \pm 2.0$ \\
\hline Undigested NDFom $^{2}$ at $30 \mathrm{~h}, \%$ of DM & $15.9 \pm 0.2$ & $16.0 \pm 0.8$ & $12.2 \pm 0.5$ & $12.1 \pm 0.4$ \\
\hline Potentially digestible NDF, ${ }^{3} \%$ of aNDFom & $76.3 \pm 1.0$ & $76.1 \pm 0.9$ & $78.4 \pm 0.5$ & $78.2 \pm 0.6$ \\
\hline pef (PSPS) ${ }^{4}$ & $0.67 \pm 0.01$ & $0.66 \pm 0.01$ & $0.66 \pm 0.01$ & $0.65 \pm 0.01$ \\
\hline peNDF (PSPS), ${ }^{5} \%$ of DM & 24.3 & 23.8 & 21.2 & 20.8 \\
\hline pef $(\text { Ro-Tap })^{6}$ & $0.67 \pm 0.02$ & $0.66 \pm 0.02$ & $0.68 \pm 0.02$ & $0.69 \pm 0.02$ \\
\hline peNDF (Ro-Tap), ${ }^{7} \%$ of DM & 24.3 & 23.8 & 21.8 & 22.1 \\
\hline
\end{tabular}

${ }^{1}$ aNDFom $=$ amylase NDF on an organic matter basis.

${ }^{2} \mathrm{NDFom}=$ neutral detergent fiber on an organic matter basis.

${ }^{3}$ Potentially digestible NDF $=($ aNDFom - undigested NDFom at $240 \mathrm{~h}) / \mathrm{aNDFom}$.

${ }^{4}$ pef $($ PSPS $)=$ physical effectiveness factor measured with the Penn State Particle Separator (Lammers et al., 1996); \% of as-fed sample $\geq 4.0$ $\mathrm{mm}$

${ }^{5}$ peNDF $($ PSPS $)=$ physically effective neutral detergent fiber [pef $\times$ aNDFom; calculated according to Mertens (1997)] using the Penn State Particle Separator.

${ }^{6}$ pef $($ Ro-Tap) $=$ physical effectiveness factor with Ro-Tap (Mentor, OH), \% of DM $\geq 1.18 \mathrm{~mm}$.

${ }^{7}$ peNDF $($ Ro-Tap $)=$ physically effective neutral detergent fiber [pef $\times$ aNDFom; calculated according to Mertens (1997)] using the Ro-Tap. 
Table 6. Analyzed concentrations and amounts of supplemental and dietary $\mathrm{Cu}, \mathrm{Mn}$, and $\mathrm{Zn}$ in diets containing either conventional corn silage $(\mathrm{CON})$ or brown midrib corn silage (BM3) with either sulfate trace minerals (STM) or hydroxy trace minerals (HTM) fed to lactating Holstein cows

\begin{tabular}{|c|c|c|c|c|}
\hline Item & \multicolumn{4}{|c|}{ Diet } \\
\hline \multicolumn{5}{|c|}{ Supplemental mineral concentration, ${ }^{1} \mathrm{mg} / \mathrm{kg}$ of $\mathrm{DM}$} \\
\hline $\mathrm{Cu}$ & 10.6 & 10.5 & 9.2 & 8.9 \\
\hline $\mathrm{Mn}$ & 41.5 & 41.2 & 41.2 & 39.6 \\
\hline $\mathrm{Cu}$ & 17.5 & 17.1 & 17.1 & 16.4 \\
\hline $\mathrm{Mn}$ & 60.5 & 68.4 & 59.9 & 63.5 \\
\hline $\mathrm{Zn}$ & 100.9 & 93.2 & 107.2 & 87.9 \\
\hline \multicolumn{5}{|c|}{ Total dietary mineral, $\mathrm{mg} / \mathrm{d}$} \\
\hline $\mathrm{Cu}$ & 493 & 469 & 468 & 458 \\
\hline $\mathrm{Mn}$ & 1,671 & 1,877 & 1,650 & 1,830 \\
\hline $\mathrm{Zn}$ & 2,767 & 2,567 & 2,943 & 2,517 \\
\hline
\end{tabular}

${ }^{1}$ Concentrations based on treatment average DMI.

silage by trace mineral interaction $(P=0.09)$. However, for all diets the time that rumen $\mathrm{pH}$ was below 5.8 was less than the concern threshold for SARA of 180 to 240 $\mathrm{min} / \mathrm{d}$ as reported by Zebeli et al. (2012). The generally low level of SARA in our study was not surprising given the relatively high dietary forage content of approximately $55 \%$ of ration DM. Stone (2004) reported that diets with peNDF content between 21 and $23 \%$ of DM would have a marginal risk of SARA, and the treatment diets in this study averaged $23 \%$ peNDF. Daily mean, standard deviation, minimum, and maximum rumen $\mathrm{pH}$ were unaffected $(P>0.10)$ by corn silage or trace mineral source. The measures of SARA (AUC $<5.8$ and $\mathrm{pH}<5.5, \mathrm{~min} / \mathrm{d})$ were also unaffected $(P>0.10)$ by corn silage or trace mineral source. In agreement with our findings, Genther and Hansen (2015) and Caldera et al. (2019) found no effect of trace mineral on rumen $\mathrm{pH}$ in cannulated beef steers.

In contrast with our findings, Pino and Heinrichs (2016) observed that Holstein heifers fed diets with organic trace minerals had lower rumen $\mathrm{pH}$ than did heifers fed diets with STM. Two potentially important differences between Pino and Heinrichs (2016) and our present study were the source of organic trace mineral (proteinates and yeast vs. HTM), and the animal model (growing dairy heifers vs. lactating dairy cows). To our knowledge, no previous study has evaluated the effect of HTM compared with STM on rumen $\mathrm{pH}$ in lactating dairy cows. It is possible that an effect of source of trace minerals fed to lactating cows might have been observed with lower forage diets that would have pre- disposed the rumen to lower pH. Future research should assess the interaction between source of trace minerals and fiber content of the diet when fed to lactating cows.

Rumen VFA data are presented in Table 8. The interactions of time of rumen fluid collection relative to feeding for corn silage, trace mineral, and corn silage by trace mineral were not statistically significant $(P$ $>0.10)$ for all measures and are not reported in Table 8. For all VFA measures, time was significant $(P<$ 0.01 ), which was expected because digestion throughout the day is dependent on substrate availability and influenced by delivery of fresh TMR and distribution of eating bouts throughout the day (Dijkstra et al., 2012).

A tendency for an interaction $(P=0.07)$ between corn silage and trace mineral source was observed for total VFA concentration. The total VFA concentration was lower for the cows fed the STM compared with HTM in the BM3 diets (116.0 vs. $121.5 \mathrm{mM}$ ), whereas the total VFA concentration was not affected by source of trace minerals in the CON diets $(116.1 \mathrm{mM})$. This was likely due to higher DMI, and consequently greater fermentable substrate, for cows fed the BM3-HTM compared with cows fed the BM3-STM as reported in a companion paper (Miller et al., 2020).

Cows fed the CON diets had greater $(P=0.02)$ acetate concentration than cows fed the BM3 diets (65.7 vs. 64.7 molar \%), which was possibly due to higher NDF content of the CON diets. Oba and Allen (2000a) reported that diets with higher NDF content had greater concentrations of rumen acetate compared with lower NDF diets. In contrast, cows fed the BM3 

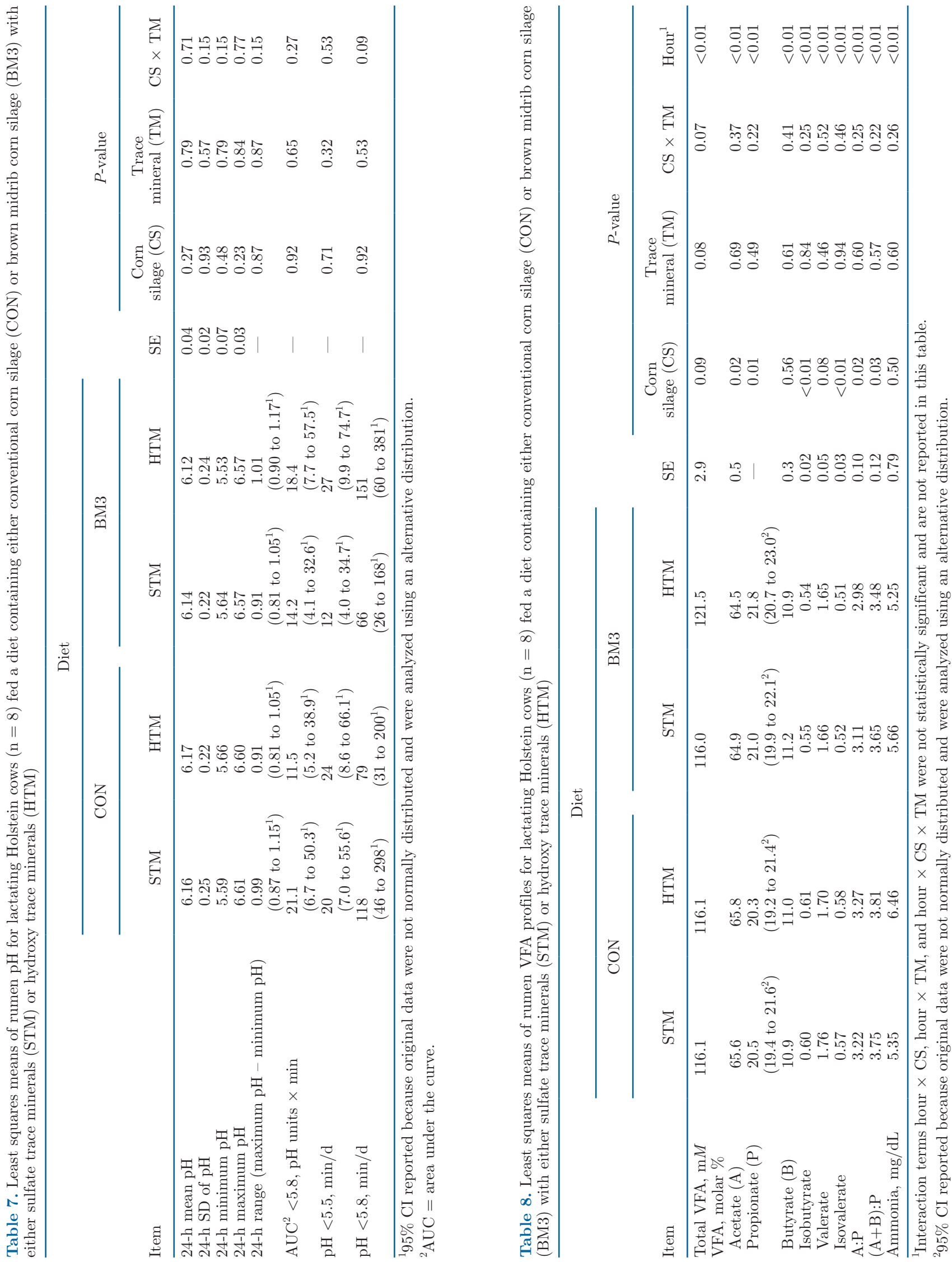
diets had greater $(P=0.01)$ propionate concentrations than cows fed the CON diets (21.4 vs. 20.4 molar \%), which was likely due to higher starch content of BM3 diets. These responses in rumen acetate and propionate track with established relationships between dietary carbohydrate (NDF and starch) content and rumen fermentation as exemplified by Oba and Allen (2003) who reported higher propionate concentrations when cows were fed high-starch compared with low-starch diets. Butyrate was unaffected $(P>0.10)$ by source of corn silage or trace mineral.

Cows fed the CON diets had greater $(P<0.01)$ concentrations of isobutyrate and isovalerate compared with cows fed the BM3 diets (0.61 vs. 0.55 molar \%; 0.58 vs. 0.52 molar $\%$, respectively). In agreement with our findings, earlier studies have reported that cows fed diets with conventional corn silage had greater concentrations of isobutyrate and isovalerate compared with cows fed diets with brown midrib-3 corn silage (Greenfield et al., 2001; Gehman et al., 2008; Hassanat et al., 2017). Gehman et al. (2008) proposed that the lower concentrations of isobutyrate and isovalerate when cows were fed brown midrib-3 corn silage are due to enhanced rumen fiber fermentation and use of branched-chain VFA by cellulolytic bacteria.

Cows fed the CON diets had a tendency for greater $(P=0.08)$ rumen concentrations of valerate compared with cows fed the BM3 diets (1.73 vs. 1.66 molar \%). Reflecting the small but significant changes in acetate and propionate concentrations, cows fed the CON diets had greater $(P<0.05)$ acetate to propionate ratio and acetate plus butyrate to propionate ratio compared with the cows fed the BM3 diets (3.25 vs. $3.04 ; 3.78$ vs. 3.57). Rumen ammonia concentration was unaffected $(P>0.10)$ by corn silage type or trace mineral source. In agreement with our findings, Pino and Heinrichs (2016) reported no effect of source of trace mineral on acetate, propionate, isobutyrate, valerate, and isovalerate concentrations, but did report that heifers fed a diet with organic trace minerals had a higher butyrate concentration than heifers fed a diet with STM. They suggested that this was due to shorter eating time for heifers fed the organic trace minerals. However, in a companion paper we did not observe a trace mineral effect on eating time (Miller et al., 2020). As previously discussed, the likely differences between Pino and Heinrichs (2016) and our current study are the source of organic trace mineral (proteinates and yeast vs. HTM) and the animal model (growing dairy heifers vs. lactating dairy cows). Similar to rumen $\mathrm{pH}$, to our knowledge, no previous study has evaluated the effect of HTM compared with STM on rumen fermentation and VFA profiles in lactating dairy cows.

\section{Rumen Digesta Pools and Turnover}

Rumen digesta characteristics, pools, and turnover are presented in Table 9. Cows fed the CON diets had greater $(P<0.05)$ rumen digesta volume and mass compared with cows fed the BM3 diets (124 vs. 119 L; 105 vs. $101 \mathrm{~kg}$ ). Rumen density was unaffected $(P$ $>0.10)$ by corn silage or trace mineral source. The differences among treatments for rumen digesta volume and mass were small and most likely not biologically important as rumen density (i.e., mass/volume) was not different $(P>0.10)$ among treatments.

A significant interaction $(P<0.01)$ between corn silage and trace mineral source was observed for rumen OM pool size, indicating that the difference among trace mineral sources was greater in the BM3 versus CON diets. A significant interaction $(P=0.04)$ between corn silage and trace mineral source was observed for $\mathrm{OM}$ turnover rate with the difference being greater among the trace mineral sources for the BM3 diets. The OM turnover time had a tendency for an interaction $(P=$ 0.10 ) between corn silage and trace mineral source. The OM turnover time was longer for cows fed the BM3HTM diet compared with cows fed the BM3-STM diet $(12.5$ vs. $11.5 \mathrm{~h})$, whereas the $\mathrm{OM}$ turnover time was not greatly affected by trace minerals in the CON diets (12.8 vs. $12.7 \mathrm{~h}$ ). Overall, the smaller rumen OM pool for cows fed the BM3-STM diets was due to a faster turnover rate compared with cows fed the BM3-HTM diets.

The rumen pool of NDF was unaffected $(P>0.10)$ by corn silage or trace mineral source. A similar study investigating the effects of conventional and brown midrib-3 corn silage in low- and high-forage diets found no measurable difference in rumen NDF pool between a high-forage diet formulated with either conventional or brown midrib-3 corn silage (Cotanch et al., 2012a). The NDF turnover rate and time were unaffected $(P>$ $0.10)$ by corn silage or trace mineral source.

A tendency for an interaction $(P=0.10)$ between corn silage and trace mineral source was observed for rumen uNDF240om pool size, reflecting the greater difference between HTM and STM for cows fed the CON diets. This effect on rumen uNDF240om pool size could be due to the different fiber characteristics of the $\mathrm{CON}$ and BM3 diets. For example, forage-based diets have resulted in greater differences in total-tract NDF digestibility between sulfate and HTM than byproductbased diets fed to lactating dairy cows (Faulkner and Weiss, 2017). In our study, cows fed the CON diets had a larger $(P<0.01)$ rumen uNDF240om pool than cows fed the BM3 diets (3.45 vs. $2.61 \mathrm{~kg})$. This was expected as CON diets had greater uNDF240om con- 
Miller et al.: CORN SILAGE AND TRACE MINERALS

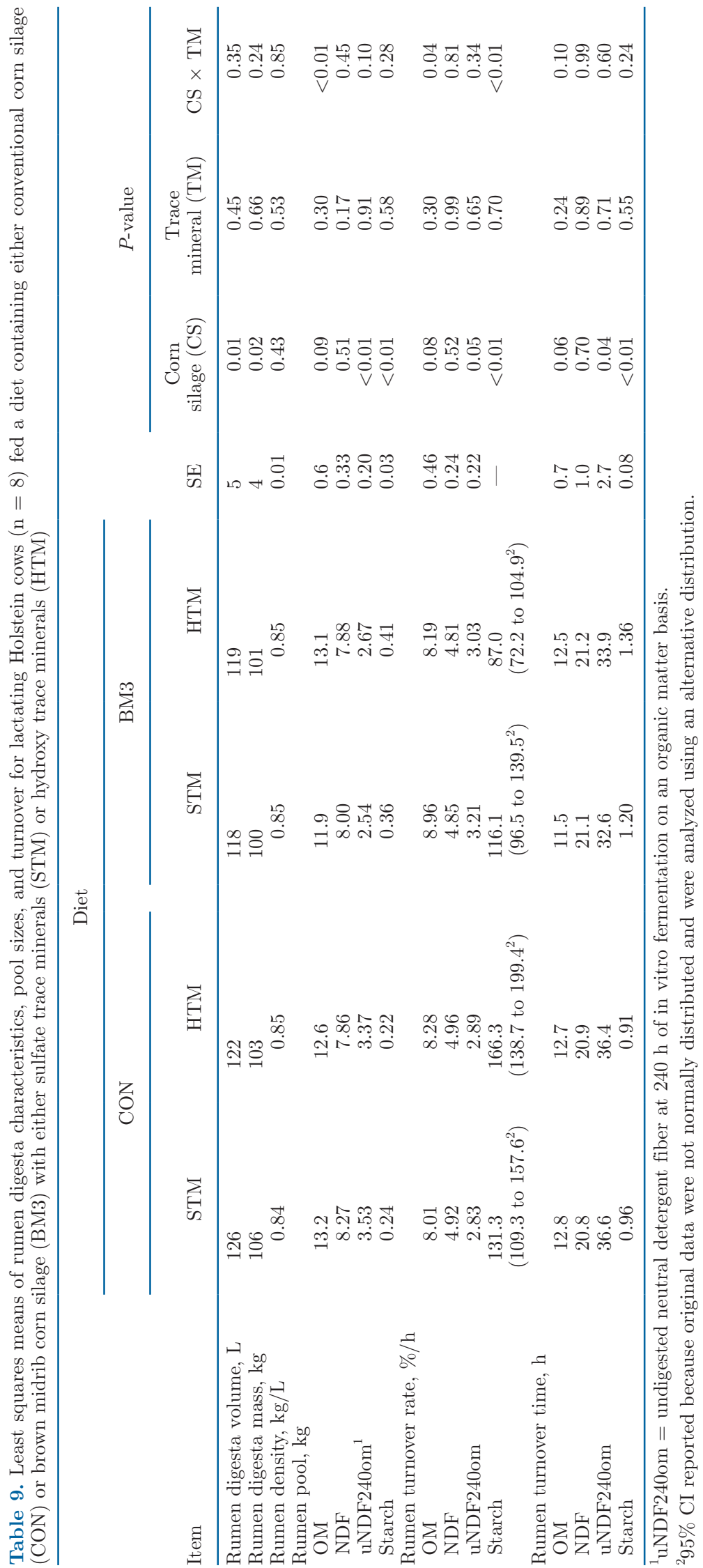


tent than the BM3 diets. Cows fed the BM3 diets had faster $(P=0.05)$ turnover rate and shorter $(P=0.04)$ turnover time for uNDF240om than cows fed the CON $\operatorname{diets}(3.12$ vs. $2.86 \% / \mathrm{h} ; 33.3$ vs. $36.5 \mathrm{~h}$, respectively). In agreement, a similarly designed study with lactating cows fed corn silage-based diets reported a faster iNDF turnover rate for cows fed diets with brown midrib-3 corn silage compared with cows fed diets with conventional corn silage (Oba and Allen, 2000b).

Cows fed the BM3 diets also had a larger rumen starch pool than cows fed the CON diets (0.38 vs. 0.23 $\mathrm{kg} ; P<0.01)$. Rumen starch pool reflected the difference in starch content between the BM3 and CON diets. An interaction $(P<0.01)$ between corn silage and trace mineral source was observed for starch turnover rate, indicating that the difference among trace mineral sources was greater for cows fed the CON diets. Cows fed the BM3 diets had longer $(P<0.01)$ turnover time for starch compared with cows fed the CON diets (0.94 vs. $1.3 \mathrm{~h}$ ). This longer turnover time could be due to a larger rumen starch pool and lower total-tract starch digestibility for cows fed the BM3 diets compared with the cows fed the CON diets. Ferraretto and Shaver (2015) reported cows fed brown midrib-3 corn silagebased diets had lower total-tract starch digestibility compared with cows fed conventional corn silage-based diets due to greater kernel vitreousness.

\section{Passage Rate of Corn Silage Particles}

Passage rate and mean retention time of marked corn silage particles are presented in Table 10. Liquid passage rate and mean retention time were unaffected $(P$ $>0.10)$ by corn silage or trace minerals. Cows fed the BM3 diets had faster $(P<0.05)$ passage rate of small and medium corn silage NDF particles than cows fed the CON diets (5.73 vs. $5.37 \% / \mathrm{h} ; 4.74$ vs. $4.31 \% / \mathrm{h}$, respectively), but passage was unaffected by trace mineral source $(P>0.10)$. For cows fed the BM3 diets, small and medium corn silage NDF particles spent 1.3 and $2.3 \mathrm{~h}$ less time in the rumen than similarly sized NDF particles for cows fed the CON diets (17.9 vs. 19.2 h, $P=0.03 ; 21.4$ vs. 23.7 h, $P<0.01$, respectively). The passage rate of large corn silage NDF particles and their mean retention time were unaffected $(P>0.10)$ by either the source of corn silage or trace mineral in the diet.

As expected, as particle size of corn silage NDF increased from small to large, the mean retention time of these particles increased. Similarly, Cotanch et al. (2012b) reported that, as forage particle size increased, so did mean retention time for cows fed conventional and brown midrib-3 corn silage in low- and high-forage diets. In the study by Cotanch et al. (2012b), cows fed the brown midrib-3 corn silage diets had faster passage rate and shorter mean retention time for small and medium corn silage NDF particles compared with cows fed the conventional corn silage diets. Likewise, Cotanch et al. (2012b) reported that cows fed high-forage diets with brown midrib-3 corn silage had shorter mean retention time for medium corn silage particles than cows fed high-forage diets with conventional corn silage diets. Our results agree with studies comparing conventional and brown midrib-3 corn silage diets where the differences in DMI and rumen fill were attributable to a lower indigestible fiber fraction and greater fiber passage rates (Oba and Allen, 1999, 2000a,b; Hassanat et al., 2017).

We observed no effect of trace mineral on passage rates of the small, medium, or large corn silage NDF particles. This was surprising because the cows fed the HTM diets had a tendency $(P=0.10)$ for greater totaltract digestibility of aNDFom than the cows fed STM diets (56.9 vs. $54.9 \%$ of DM; Miller et al., 2020). The release of free metals in the rumen could have negative effects on cellulolytic bacteria or bind to undigested fractions (e.g., fiber fractions) that pass from the rumen (Torre et al., 1991; Genther and Hansen, 2015; Faulkner et al., 2017). If the free minerals were binding to corn silage particles and affecting their fermentability, then these minerals possibly could alter the buoyancy of the particle, and potentially affect the passage of undigested fiber particles from the rumen.

The process of marking the corn silage particles with rare earth could also be a reason for not observing a trace mineral effect. The particles underwent an extensive process to be marked including neutral detergent extraction, soaking in a rare earth solution for $48 \mathrm{~h}$, and then rinsing with a weak acid for $3 \mathrm{~h}$. In theory, the majority of the available binding sites should have had a rare earth attached, which would limit the free metals from disassociated trace mineral complexes from binding. Further research is needed to identify the mechanism of how trace minerals affect total-tract aNDFom digestibility as described in the companion paper (Miller et al., 2020).

\section{CONCLUSIONS}

Source of corn silage influenced rumen dynamics as the greater in vitro NDF digestibility and lower uNDF240om content allowed for a faster turnover rate of iNDF and faster passage rates of small and medium corn silage particles. Source of trace mineral did not have a great effect on rumen characteristics and particle passage rate although we observed a corn silage by trace mineral interaction on OM and uNDF240om pool size and OM turnover. It appears that any influence of 
Miller et al.: CORN SILAGE AND TRACE MINERALS

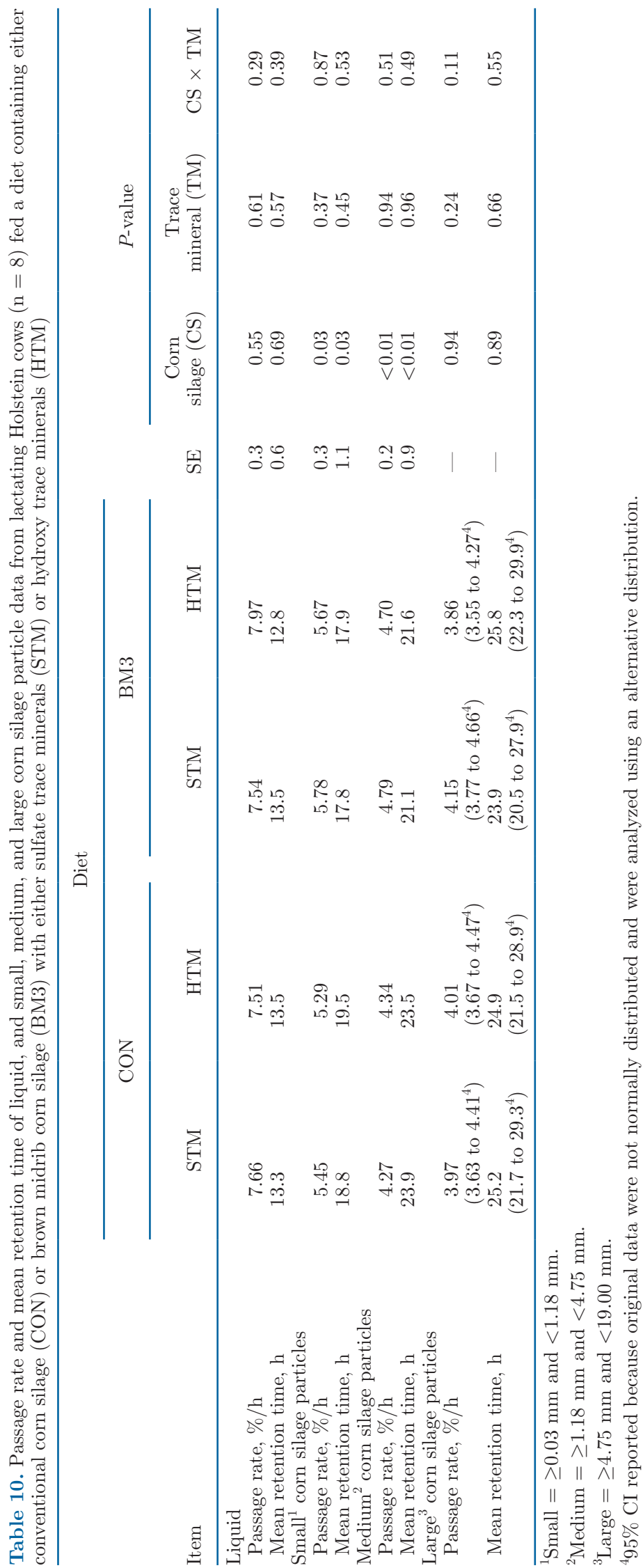


the source of trace mineral on intake or digestibility is not primarily effected through changes in rumen $\mathrm{pH}$, VFA ratios, digesta turnover, or particle passage. More research is needed to identify the mechanism of how trace minerals influence DMI and total-tract aNDFom digestibility.

\section{ACKNOWLEDGMENTS}

We thank Micronutrients USA LLC (Indianapolis, IN) for partially funding this experiment and the farm and research staff at the William H. Miner Agricultural Research Institute for care of the cows. The authors have not stated any conflicts of interest.

\section{REFERENCES}

Allen, M. S., and D. R. Mertens. 1988. Evaluating constraints on fiber digestion by rumen microbes. J. Nutr. 118:261-270. https://doi .org $/ 10.1093 /$ jn $/ 118.2 .261$.

AOAC International. 2012. Official Methods of Analysis. 19th ed. AOAC International, Arlington, VA.

Beauchemin, K. A., and W. Z. Yang. 2005. Effects of physically effective fiber on intake, chewing activity, and ruminal acidosis for dairy cows fed diets based on corn silage. J. Dairy Sci. 88:21172129. https://doi.org/10.3168/jds.S0022-0302(05)72888-5.

Caldera, E., B. Weigel, V. N. Kucharczyk, K. S. Sellins, S. L. Archibeque, J. J. Wagner, H. Han, J. W. Spears, and T. E. Engle. 2019. Trace mineral source influences ruminal distribution of copper and zinc and their binding strength to ruminal digesta. J. Anim. Sci. 97:1852-1864. https://doi.org/10.1093/jas/skz072.

Cao, J., P. R. Henry, C. B. Ammerman, R. D. Miles, and R. C. Littell. 2000. Relative bioavailability of basic zinc sulfate and basic zinc chloride for chicks. J. Appl. Poult. Res. 9:513-517. https://doi .org/10.1093/japr/9.4.513.

Chaney, A. L., and E. P. Marbach. 1962. Modified reagents for determination of urea and ammonia. Clin. Chem. 8:130-132. https:// doi.org/10.1093/clinchem/8.2.130.

Cotanch, K. W., R. J. Grant, M. E. Van Amburgh, A. Zontini, M. Fustini, A. Palmonari, and A. Formigoni. 2014. Applications of uNDF in ration modeling and formulation. Pages 114-131 in Proc. 2014 Cornell Nutr. Conf. for Feed Manufacturers, Syracuse, NY. Cornell University, Ithaca, NY.

Cotanch, K. W., C. Kokko, H. M. Dann, J. W. Darrah, and R. J. Grant. 2012a. Amount and digestibility of NDF affects rumen nutrient pool sizes and passage kinetics of dairy cows. J. Dairy Sci. 95(Suppl. 1):181. (Abstr.)

Cotanch, K. W., C. Kokko, H. M. Dann, J. W. Darrah, R. J. Grant, and D. R. Mertens. 2012b. Passage of liquid and fiber particles in dairy cows fed diets differing in NDF from conventional and BMR corn silages. J. Dairy Sci. 95(Suppl. 1):181. (Abstr.)

Dijkstra, J., J. L. Ellis, E. Kebreab, A. B. Strathe, S. Lopez, J. France, and A. Bannink. 2012. Ruminal pH regulation and nutritional consequences of low pH. Anim. Feed Sci. Technol. 172:22-33. https:// doi.org/10.1016/j.anifeedsci.2011.12.005.

DuBois, M., K. A. Gilles, J. K. Hamilton, P. A. Rebers, and F. Smith. 1956. Calorimetric method for determination of sugars and related substances. Anal. Chem. 28:350-356. https://doi.org/10.1021/ ac60111a017.

Ellis, W. C., and D. E. Beever. 1984. Methods for binding rare earths to specific feed particles. Pages 154-165 in Techniques in Particle Size Analysis of Feed Analysis of Feed and Digesta in Ruminants. P. M. Kennedy, ed. Occas. Publ. No. 1. Can. Soc. Anim. Sci., Edmonton, Alberta, Canada.

Faulkner, M. J., N. R. St-Pierre, and W. P. Weiss. 2017. Effect of source of trace minerals in either forage- or by-product-based diets fed to dairy cows: 2. Apparent absorption and retention of minerals. J. Dairy Sci. 100:5368-5377. https://doi.org/10.3168/jds.2016 -12096 .

Faulkner, M. J., and W. P. Weiss. 2017. Effect of source of trace minerals in either forage- or by-product-based diets fed to dairy cows: 1. Production and macronutrient digestibility. J. Dairy Sci 100:5358-5367. https://doi.org/10.3168/jds.2016-12095.

Ferraretto, L. F., and R. D. Shaver. 2015. Effects of whole-plant corn silage hybrid type on intake, digestion, ruminal fermentation, and lactation performance by dairy cows through a meta-analysis. J. Dairy Sci. 98:2662-2675. https://doi.org/10.3168/jds.2014-9045.

Gehman, A. M., P. J. Kononoff, C. R. Mullins, and B. N. Janicek. 2008. Evaluation of nitrogen utilization and the effects of monensin in dairy cows fed brown midrib corn silage. J. Dairy Sci. 91:288-300. https://doi.org/10.3168/jds.2007-0098.

Genther, O. N., and S. L. Hansen. 2015. The effect of trace mineral source and concentration on ruminal digestion and mineral solubility. J. Dairy Sci. 98:566-573. https://doi.org/10.3168/jds.2014 -8624 .

Goering, H. K., and P. J. Van Soest. 1970. Forage Fiber Analysis: Apparatus, Reagents, Procedures, and Some Applications. Agric. Handbook No. 379. Agricultural Research Service, USDA, Washington. DC.

Grant, R. J., and A. T. Adesogan. 2018. Journal of Dairy Science silage special issue: Introduction. J. Dairy Sci. 101:3935-3936. https: //doi.org/10.3168/jds.2018-14630.

Greenfield, T. L., R. L. Baldwin, R. A. Erdman, and K. R. McLeod. 2001. Ruminal fermentation and intestinal flow of nutrients by lactating cows consuming brown midrib corn silages. J. Dairy Sci 84:2469-2477. https://doi.org/10.3168/jds.S0022-0302(01)74697 -8 .

Grovum, W. L., and V. Williams. 1973. Rate of passage of digesta in sheep: 4. Passage of marker through the alimentary tract and the biological relevance of rate-constants derived from the changes in concentration of marker in faeces. Br. J. Nutr. 30:313-329. https:/ /doi.org/10.1079/BJN19730036.

Hall, M. B. 2009. Determination of starch, including maltooligosaccharides, in animal feeds: Comparison of methods and a method recommended for AOAC collaborative study. J. AOAC Int. 92:42-49. https://doi.org/10.1093/jaoac/92.1.42.

Hassanat, F., R. Gervais, and C. Benchaar. 2017. Methane production, ruminal fermentation characteristics, nutrient digestibility, nitrogen excretion, and milk production of dairy cows fed conventional or brown midrib corn silage. J. Dairy Sci. 100:2625-2636. https:// doi.org/10.3168/jds.2016-11862.

Krishnamoorthy, U., T. V. Muscato, C. J. Sniffen, and P. J. Van Soest. 1982. Nitrogen fractions in selected feedstuffs. J. Dairy Sci. 65:217-225. https://doi.org/10.3168/jds.S0022-0302(82)82180-2.

Lammers, B. P., D. R. Buckmaster, and A. J. Heinrichs. 1996. A simple method for the analysis of particle sizes of forage and total mixed rations. J. Dairy Sci. 79:922-928. https://doi.org/10.3168/ jds.S0022-0302(96)76442-1.

Mertens, D. R. 1997. Creating a system for meeting the fiber requirements of dairy cows. J. Dairy Sci. 80:1463-1481. https://doi.org/ 10.3168/jds.S0022-0302(97)76075-2.

Mertens, D. R. 2005. Rate and extent of digestion. Pages 13-47 in Quantitative Aspects of Ruminant Digestion and Metabolism, 2nd ed. J. Dijkstra, J. M. Forbes, and J. France, ed. CABI Publishing, Wallingford, UK.

Miller, M. D., J. S. Lanier, S. K. Kvidera, H. M. Dann, C. S. Ballard, and R. J. Grant. 2020. Evaluation of source of corn silage and trace minerals on lactational performance and total tract nutrient digestibility of Holstein cows. J. Dairy Sci. 103:3147-3160. https:/ /doi.org/10.3168/jds.2019-17716.

Miller, M. D., E. O. Young, K. W. Cotanch, C. S. Ballard, and R. J. Grant. 2018. Yield and quality of brown midrib and non-brown midrib corn silage hybrids grown in Northern New York over a three-year period. J. Dairy Sci. 101(Suppl. 2):62. (Abstr.)

Nousiainen, J., M. Rinne, M. Hellamaki, and P. Huhtanen. 2003. Prediction of the digestibility of the primary growth of grass silages harvested at different stages of maturity from chemical compo- 
sition and pepsin-cellulase solubility. Anim. Feed Sci. Technol. 103:97-111. https://doi.org/10.1016/S0377-8401(02)00283-3.

NRC. 2001. Nutrient Requirements of Dairy Cattle. 7th rev. ed. National Academy Press, Washington, DC.

Oba, M., and M. S. Allen. 1999. Effects of brown midrib 3 mutation in corn silage on dry matter intake and productivity of high yielding dairy cows. J. Dairy Sci. 82:135-142. https://doi.org/10.3168/jds .S0022-0302(99)75217-3.

Oba, M., and M. S. Allen. 2000a. Effects of brown midrib 3 mutation in corn silage on productivity of dairy cows fed two concentration of dietary neutral detergent fiber: 1 . Feeding behavior and nutrient utilization. J. Dairy Sci. 83:1333-1341. https://doi.org/10.3168/ jds.S0022-0302(00)75000-4.

Oba, M., and M. S. Allen. 2000b. Effects of brown midrib 3 mutation in corn silage on productivity of dairy cows fed two concentration of dietary neutral detergent fiber: 3. Digestibility and microbial efficiency. J. Dairy Sci. 83:1350-1358. https://doi.org/10.3168/jds S0022-0302(00)75002-8.

Oba, M., and M. S. Allen. 2003. Effects of corn grain conservation method on feeding behavior and productivity of lactating dairy cows at two dietary starch concentrations. J. Dairy Sci. 86:174183. https://doi.org/10.3168/jds.S0022-0302(03)73598-X.

Penner, G. B., K. A. Beauchemin, and T. Mutsvangwa. 2006. An evaluation of the accuracy and precision of a stand-alone submersible continuous ruminal $\mathrm{pH}$ measurement system. J. Dairy Sci. 89:2132-2140. https://doi.org/10.3168/jds.S0022-0302(06)72284 $-6$

Pino, F., and A. J. Heinrichs. 2016. Effect of trace minerals and starch on digestibility and rumen fermentation in diets for dairy heifers. J. Dairy Sci. 99:2797-2810. https://doi.org/10.3168/jds.2015 -10034 .

R Core Team. 2014. R: a language and environment for statistical computing. R Foundation for Statistical Computing, Vienna, Austria. http://www.R-project.org/.

Raffrenato, E., D. A. Ross, and M. E. Van Amburgh. 2018. Development of an in vitro method to determine rumen undigested aNDFom for use in feed evaluation. J. Dairy Sci. 101:9888-9900. https: //doi.org/10.3168/jds.2018-15101.
Spears, J. W., E. B. Kegley, and L. A. Mullis. 2004. Bioavailability of copper from tribasic copper chloride and copper sulfate in growing cattle. Anim. Feed Sci. Technol. 116:1-13. https://doi.org/10 .1016/j.anifeedsci.2004.06.002.

Stone, W. C. 2004. Nutritional approaches to minimize subacute ruminal acidosis and laminitis in dairy cattle. J. Dairy Sci. 87:(E. Suppl.):E13-E26.

Torre, M., A. R. Rodriguez, and F. Saura-Calixto. 1991. Effects of dietary fiber and phytic acid on mineral availability. Crit. Rev. Food Sci. Nutr. 30:1-22. https://doi.org/10.1080/10408399109527539.

Udén, P. P. E. Colucci, and P. J. Van Soest. 1980. Investigation of chromium, cerium and cobalt as markers in digesta. Rate of passage studies. J. Sci. Food Agric. 31:625-632. https://doi.org/10 .1002/jsfa.2740310702.

Van Soest, P. J., J. B. Robertson, and B. A. Lewis. 1991. Methods for dietary fiber, neutral detergent fiber, and nonstarch polysaccharides in relation to animal nutrition. J. Dairy Sci. 74:3583-3597. https://doi.org/10.3168/jds.S0022-0302(91)78551-2.

Voelker Linton, J. A., and M. S. Allen. 2008. Nutrient demand interacts with forage family to affect intake and digestion responses in dairy cows. J. Dairy Sci. 91:2694-2701. https://doi.org/10.3168/ jds.2007-0897.

Zebeli, Q., B. U. Metzler-Zebeli, and B. N. Ametaj. 2012. Meta-analysis reveals threshold level of rapidly fermentable dietary concentrate that triggers systemic inflammation in cattle. J. Dairy Sci. 95:2662-2672. https://doi.org/10.3168/jds.2011-5080.

\section{ORCIDS}

M. D. Miller ํㅜ https://orcid.org/0000-0002-1448-6289

J. S. Lanier ( $\odot$ https://orcid.org/0000-0003-3043-7820

H. M. Dann () https://orcid.org/0000-0002-7372-7011

C. S. Ballard ๑ https://orcid.org/0000-0002-1371-2256

R. J. Grant ๑ https://orcid.org/0000-0001-5797-9916 